\title{
Seed production of tomato varieties depending on planting schemes and fertilizers in the conditions of Southern Steppe
}

\author{
Kosenko N. ${ }^{1}$, Pohorielova V. ${ }^{2}$ \\ Institute of Irrigated Agriculture of NAAS, Naddniprianske, Kherson, 73483, Ukraine \\ e-mail: ${ }^{1} n d z . k o s e n k o @ g m a i l . c o m,{ }^{2}$ pogorelova19918@gmail.com
}

Goal. To determine the influence of planting schemes and fertilizing on the cultivation of different varieties of tomato, their yield and sowing quality of seeds in the conditions of Southern Steppe of Ukraine. Methods. Field, laboratory, calculation, comparative, mathematical-and-statistical analysis. Results. It is established that the seed yield had the influence of the studied factors. The average yield for 2016-2018 for the variety Lehin was 117,62 kg/ha, for the variety Yuvileinyi $-112,63 \mathrm{~kg} / \mathrm{ha}$. On average over the years of researches, it is established that the yield in the scheme of seeding $100+50 \mathrm{~cm}$ was on $0.6 \%$ more than in the scheme of seeding $150 \mathrm{~cm}$. Minimum seed yield is obtained in the variant without fertilizers - 49,06 kg/ha. Application of the organo-mineral system, combined with foliar feeding had a positive impact on the seed productivity of tomato plants. The increase in the yield of seeds made $56.95-67,04 \%$ as compared to non-fertilized plots. The seeds obtained in the variants of the experiment had propagation energy of $81-90 \%$, and germination rate $-95-100 \%$. Fertilizing increased the weight of 1000 seeds on $0,06-0,11 \mathrm{~g}$, germination energy $-1-3 \%$. Conclusions. Seed efficiency was significantly influenced by fertilizers. Variety and sowing scheme to a lesser extent influenced the seed yield. The highest seed yield $(159,91 \mathrm{~kg} / \mathrm{ha})$ provided the variety Lehin at the use of a planting scheme of $100+50 \mathrm{~cm}$ and complex fertilizing. The significant effect of the studied factors on sowing qualities of seeds of tomato was not detected. The highest level of profitability $(154 \%)$ provided the variety Lehin at the use of planting scheme $150 \mathrm{~cm}$ and mineral fertilizers with foliar feeding by Plantafol.

Key words: yield, germination energy, plant nutrition, seed quality.

DOI: https://doi.org/10.31073/agrovisnyk202002-06

The use of high quality seed is one of perspective ways of increase of the productivity of tomato plants. Seeds are the source of biological, genetic and economic signs and it is able to provide the high commodity productivity and high quality of vegetables. Application of effective elements of technology, optimal conditions during the impregnation of flowers, forming of harvest and ripening of seed assist the receipt of seed of high quality [3]. Time of harvesting, selection, washing, drying and storage of seed is very important in a seed growing [4]. The seed production of domestic sorts and hybrids of vegetable plants does not answer modern requirements. There is strengthening of competition from the side of foreign seed on this time at the Ukrainian market [5]. The Ukrainian scientists claim that it is necessary to provide priorities to domestic grades and hybrids for the purpose of bringing their share in the register of plant varieties to $50 \%$ [6]. Therefore, improvements and implementation of modern technologies of cultivation of sorts of domestic selection that will allow to increase a harvest and to improve quality of seeds now, is very actual.

By researches of many scientists it is established that seed productivity significantly depends on high quality features and conditions of cultivation of seed plants. In the irrigated conditions of the South of Ukraine researches on development of basic elements of technology of cultivation of tomato seeds were conducted. In cultivation from seeds the seed productivity was from 63,5 to $94.4 \mathrm{~kg} / \mathrm{ha}$ for the variety Naddnepryanskiy 1 , that it is suitable for harvest by the combine.

The field experiment of determinate varieties of tomatoes (Bishola, Chali, Cochoro, Fetan, Melkasalsa), indeterminate (Metadel, Miya, Melkashola, Arptomato) and variety Roma VF showed, that a high yield of seed was characterize Bishola $177.26 \mathrm{~kg} / \mathrm{ha}$ and Melkasalsa $150.81 \mathrm{~kg} / \mathrm{ha}$. The productivity of seed of variety Roma VF presented $114.88 \mathrm{~kg} / \mathrm{ha}$. The yield of seed of other varieties was within the limits of $58.11-108.00 \mathrm{~kg} / \mathrm{ha}$ [8]. Studies of fertilization of microelements on seed yields have shown that foliar treatment of plants stimulates an increase the vegetative mass and seed productivity of tomato plants. Under the conditions of spraying tomato plants with a boron solution, seed yield was $193.35 \mathrm{~kg} / \mathrm{ha}$. The seed yield $206.72 \mathrm{~kg} / \mathrm{ha}$ was obtained by processing a solution of zinc sulfate. Less influence on tomato plants was consumed by zinc sulfate, the increase was $22.34 \mathrm{~kg} / \mathrm{ha}$. The lowest yield $150.74 \mathrm{~kg} / \mathrm{ha}$ were in the control variant (without treatment with microelements) [9]. The influence of foliar application of boron and zinc on yield and quality of seed was studied in experiments at method of growing. At application mineral fertilizers in the dose $\mathrm{N}_{120} \mathrm{P}_{90} \mathrm{~K}_{60}$ and foliar treatment $\mathrm{B}_{100} \mathrm{Zn}_{100}$ three times during the growing season contributed to an increase in the number of lateral shoots from 4 to 10 pieces, leaves from 54 to 76 and the yield of seeds from one fruit from 4.05 to $6,0 \mathrm{~g}$. The maximum seed yield $445,54 \mathrm{~kg} / \mathrm{ha}$, was obtained by sprinkling of $B_{100} Z n_{100}$, which is on $144.8 \mathrm{~kg} / \mathrm{ha}(48.2 \%)$ more, than without 
processing. Other combinations of norms of boron and zinc increased the yield of seeds by $5.4-27.4 \%$ compared with the control variant [10]. Organic fertilizers are given the most important place in the system of measures to increase the yield of agricultural crops and soil fertility. This is due to the fact that they not only enrich the soil with elements of nutrition, but also improve its physical properties. The use of biological preparations has a significant impact on the productivity of many cultures; therefore it is advisable to study the effect on the productivity of tomato plants. Under the biological means are understood the specially prepared biological preparations, containing microorganisms and other biological agents, as well as components, intended for conservation of biological agents properties during their storing and use [11].

The purpose. To determine the effect of the scheme of sowing and fertilization on the yield of seeds of tomato and sowing qualities of seeds in the conditions of Southern Steppe of Ukraine is our purpose of researches.

Materials and methods. The researches were conducted on the experimental field of the vegetable growing laboratory of the Institute of Irrigated Faming of Ukraine in 2016-2018. The soil of the experimental field is dark chestnut. For this soil is characterized by a weak salinity and the average content of clay fraction. Humus contents in arable $(0-30 \mathrm{~cm})$ a layer of earth $2.14 \%$, total nitrogen $2.24 \%$, mobile phosphorus and exchangeable potassium respectively 62 and $323 \mathrm{mg} / \mathrm{kg}$ of soil. The lowest moisture content in the meter layer of soil is $21.3 \%$, the moisture content of the wilting is $9.5 \%$ of the dry ground weight. The density of the soil structure is $1.41 \mathrm{~g} / \mathrm{cm}^{3}$. The $\mathrm{pH}$ of the aqueous extraction of the arable layer of soil is 7.2. The technology of cultivating seed plants in the experiment is generally accepted for irrigation conditions in the south of Ukraine, except for the elements studied, according to the following scheme: factor A - tomato variety: Legin, Jubilee; factor B - scheme of sowing: $100+50 \mathrm{~cm}$, $150 \mathrm{~cm}$; factor $\mathrm{C}$ - fertilizer of plants: 1) without fertilizers (control); 2) the estimated dose of mineral fertilizers; 3 ) the estimated dose of fertilizers and foliar treatment with Plantafol; 4) the estimated dose of fertilizers and Bioproferm; 5) Estimated fertilizer dose, Bioproferm and Plantafol. Our Researches conducted growing of plants at method cultivation from seed with the use of drip irrigation. During the vegetation applied the differentiated mode of irrigation after the phases of development of plants. The sown area was of $14 \mathrm{~m}^{2}$, the accounted area was of $10 \mathrm{~m}^{2}$. The research had four times reoccurrence. Estimated dose of fertilizers $\mathrm{N}_{219} \mathrm{P}_{10} 2 \mathrm{~K}_{40}$, that was determined for the harvest of fruits 80 T/ha.

The bioproferme is organic fertilizer, in one ton of which contains active substance nitrogen $10-15 \mathrm{~kg}$, phosphorus $-9-14 \mathrm{~kg}$ a.s., potassium $-6-10 \mathrm{~kg}$ a.s., calcium $-10-30 \mathrm{~kg}$ a.s. The introduction of this preparation on experimental plots was carried out at the rate of $6 \mathrm{t} / \mathrm{ha}$. Foliar application with Plantafol was performed four times for the vegetation of plants: the first - Plantafol $\mathrm{N}_{10} \mathrm{P}_{54} \mathrm{~K}_{10}$, the next three Plantafol $\mathrm{N}_{20} \mathrm{P}_{20} \mathrm{~K}_{20}$. On the experimental sites, varieties of tomato breeding were planted at the Institute of Irrigation Farming of the National Academy of Sciences of Ukraine.

The variety Legin is the middle-aged by the period of reaching. The vegetative period from mass stairs to the beginning of maturation is 110-112 days. Plant by type of growth is determinant, height $50-55 \mathrm{~cm}$. The first inflorescence is laid over 6-7 leaf, the following $-1-2$ leaves. The fruits have an elliptical shape (index 1.15), reaching red color, without green spots in the peduncle, weighing 65-70 g. Fruits are dense, fleshy, not cracked, high transportability. The variety is suitable for combine harvesting of fruits. The content in the fruit of a soluble dry substance is $5.6-5.9 \%$, total sugars $3.2-3.5 \%$, ascorbic acid 21.5$22.5 \mathrm{mg} / 100 \mathrm{~g}$. The variety is entered in the Register of plant varieties of Ukraine since 2013.

The variety Jubilee is the middle-agedby the period of reaching. The vegetative period from mass stairs to the beginning of maturation is 112-115 days. Plant by type of growth is determinant, height 50 $55 \mathrm{~cm}$. The first inflorescence is laid over 6-7 leaf, the following $-1-2$ leaves. The fruits are reversedegg-shaped (index 1.3), for reaching red color, without a green spot in the peduncle, weight $-90-100 \mathrm{~g}$. Fruits are dense, fleshy, have high portability. The variety is suitable For fruit harvesting, the content in the fruit of a soluble dry matter is $5.7-5.9 \%$, total sugars are $3.3-3.5 \%$, ascorbic acid is $22.5-$ $23.5 \mathrm{mg} / 100 \mathrm{~g}$. The variety Jubilee is undergoing state variety testing. When laying the test and performing related studies, guided by generally accepted methodological recommendations for growing of vegetable and melon plants $[12,13]$. The selection of fruits for the separation of seeds was carried out with 2-4 inflorescences in the phase of maturation. The weight of the test sample was $10 \mathrm{~kg}$ for seed separation. Seeds were extracted from fully mature red ripe fruits. Separation of seeds was carried out manually, followed by fermentation within 1-3 days. After washing the seeds in water, it was dried to a moisture content of $14 \%$. Seed yield per ha was calculated based on seed yield per plot and expressed in kilogram per hectare.

Sowing quality of seeds was determined according to the normative and technical state standards: DSTU 7160: 2010 and DSTU 4138-2002. Germination energy and laboratory germination was determined using the standard laboratory method. In each variance, 4x100 seeds were tested. Wet sterilized sand was used as the medium and the seeds were incubated in a germination chamber at a temperature of $23-25 \circ \mathrm{C}$ and $95 \%$ relative humidity. Germination energy was assessed on the fifth day, laboratory germination on tenth day by counting the number of typical seedlings. The statistical and cross-correlation analyses of results of researches conducted, using LSD value at $5 \%$ significance level. 
During realization of researches drew on the complex of methods, namely: the field, instrumentationcalculation, comparative, mathematically-statistical analyses.

Meteorological conditions during vegetation periods in the years of researches differed on basic hydrothermal indexes (temperature, precipitations) from long-term data. Weather conditions were on the whole friendly to growing tomato plants. For vegetation period (April-September) in 2016 precipitations are $674 \mathrm{~mm}$ fell out, in $2017-406 \mathrm{~mm}$, in $2018-341 \mathrm{~mm}$. The irrigation rate in 2016 presented $1430 \mathrm{~m}^{3} / \mathrm{ha}$, in $2017-1243 \mathrm{~m}^{3} / \mathrm{ha}$, in $2018-1619 \mathrm{~m}^{3} / \mathrm{ha}$.

The results of the researches. The main indicator of the performance of the seed is an index of the unit area yield of seeds. Found that yields seeds had the influence of the studied factors. Yield of seeds in 2016 , for the variety Legìn was within $40.36-164.88 \mathrm{~kg} / \mathrm{ha}$, to variety Jubilee $44.74-139.61 \mathrm{~kg} / \mathrm{ha}$ (Table).

\section{Yield of seeds of tomato, depending on the factors examined}

\begin{tabular}{|c|c|c|c|c|c|c|}
\hline \multirow{2}{*}{ 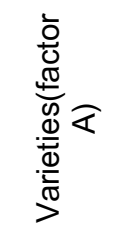 } & \multirow{2}{*}{ 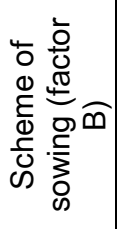 } & \multirow{2}{*}{ Fertilization (factor C) } & \multicolumn{4}{|c|}{ Yield of seed, $\mathrm{kg} / \mathrm{ha}$} \\
\hline & & & 2016 & 2017 & 2018 & $\begin{array}{l}2016- \\
2018\end{array}$ \\
\hline \multirow{10}{*}{ 鸪 } & \multirow{5}{*}{$\begin{array}{l}\varepsilon \\
\infty \\
o \\
1 \\
+ \\
8 \\
0\end{array}$} & Monitoring (without fertilizers) & 41,85 & 45,93 & 54,45 & 47,41 \\
\hline & & estimated dose of mineral fertilizers & 114,93 & 118,60 & 106,85 & 113,46 \\
\hline & & Estimated dose of mineral fertilizers Plantafol; & 133,41 & 136,42 & 126,88 & 132,24 \\
\hline & & Organic (Bioproferm) and mineral fertilizer & 127,15 & 126,71 & 144,46 & 132,77 \\
\hline & & $\begin{array}{l}\text { Organic (Bioproferm), mineral fertilizer and } \\
\text { foliar application (Plantafol }\end{array}$ & 164,88 & 154,32 & 160,53 & 159,91 \\
\hline & \multirow{5}{*}{ 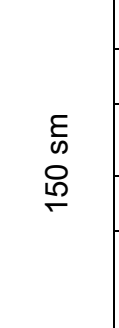 } & Monitoring (without fertilizers) & 40,36 & 43,41 & 59,35 & 47,71 \\
\hline & & estimated dose of mineral fertilizers & 128,52 & 120,67 & 101,02 & 116,74 \\
\hline & & $\begin{array}{l}\text { Estimated dose of mineral fertilizers+ } \\
\text { Plantafol; }\end{array}$ & 145,87 & 137,64 & 139,15 & 140,88 \\
\hline & & Organic (Bioproferm) and mineral fertilizer & 121,60 & 127,17 & 149,74 & 132,84 \\
\hline & & $\begin{array}{l}\text { Organic (Bioproferm), mineral fertilizer and } \\
\text { foliar application (Plantafol) }\end{array}$ & 153,40 & 150,78 & 152,59 & 152,26 \\
\hline \multirow{10}{*}{$\begin{array}{l}\frac{\Phi}{\Phi} \\
\frac{\Phi}{\overline{0}}\end{array}$} & \multirow{5}{*}{$\begin{array}{l}\varepsilon \\
\infty \\
o \\
p \\
+ \\
0 \\
0\end{array}$} & Monitoring (without fertilizers) & 44,93 & 43,94 & 74,18 & 54,35 \\
\hline & & estimated dose of mineral fertilizers & 118,88 & 117,17 & 114,98 & 117,01 \\
\hline & & $\begin{array}{l}\text { Estimated dose of mineral fertilizers+ } \\
\text { Plantafol }\end{array}$ & 134,43 & 109,22 & 134,91 & 126,19 \\
\hline & & Organic (Bioproferm) and mineral fertilizer & 126,48 & 128,66 & 137,79 & 130,98 \\
\hline & & $\begin{array}{l}\text { Organic (Bioproferm), mineral fertilizer and } \\
\text { foliar application (Plantafol) }\end{array}$ & 139,10 & 138,71 & 143,00 & 140,27 \\
\hline & \multirow{5}{*}{$\begin{array}{l}E \\
\text { क } \\
\text { ○ } \\
\stackrel{1}{n}\end{array}$} & Monitoring (without fertilizers) & 44,74 & 35,91 & 59,70 & 46,78 \\
\hline & & estimated dose of mineral fertilizers & 111,93 & 122,42 & 91,72 & 108,69 \\
\hline & & $\begin{array}{l}\text { Estimated dose of mineral fertilizers+ } \\
\text { Plantafol) }\end{array}$ & 129,29 & 131,16 & 121,46 & 127,30 \\
\hline & & Organic (Bioproferm) and mineral fertilizer & 125,83 & 129,02 & 140,50 & 131,78 \\
\hline & & $\begin{array}{l}\text { Organic (Bioproferm), mineral fertilizer and } \\
\text { foliar application (Plantafol) }\end{array}$ & 139,61 & 143,94 & 145,39 & 142,98 \\
\hline \multicolumn{3}{|c|}{$\mathrm{LSD}_{05}$ factor $\mathrm{A}$ (varieties) } & 1,99 & 9,02 & 9,49 & 4,17 \\
\hline \multicolumn{3}{|c|}{$\mathrm{LSD}_{05}$ factor $\mathrm{B}$ (scheme of sowing) } & 3,90 & 5,73 & 6,87 & 1,62 \\
\hline \multicolumn{3}{|c|}{ LSD $_{05}$ factor C (fertilization) } & 5,40 & 4,29 & 6,91 & 3,40 \\
\hline
\end{tabular}

Comparison of the seed productivity of the two varieties showed that the yield of the varieties Legin was $117.62 \mathrm{~kg} / \mathrm{ha}$, which is $4.99 \mathrm{~kg} / \mathrm{ha}$ more than the variety Jubilee $\left(\mathrm{LSD}_{05}=4.17\right)$. Schemes of sowing didn't have a significant impact on yield. By the scheme $100+50 \mathrm{sm}$, an increase in yields was noted at $0.66 \mathrm{~kg} / \mathrm{ha}$, which is $0.6 \%$. 
Fertilizer is a powerful factor in increasing yields. The use of fertilizers, taking into account the effective fertility of the soil and the needs of plants in nutrients, gives an opportunity to increase yields. Substantial positive effect was observed foliar application of tomato plants. To reduce the toxic effect of mineral fertilizers on tomato plants, it is rationally partly replaced by organic fertilizers. It should be noted that the maximum yield is achieved for the integrated use of mineral, organic fertilizers and foliar application. It was proved that the factor $\mathrm{C}$ was the most influence on seed yield formation.

The minimum yield of seeds was obtained without fertilization and was $49.06 \mathrm{~kg} / \mathrm{ha}$. The application of fertilizers had a positive effect on the yield of tomato seeds. Thus, for the use of mineral fertilizers, the seed yield on average increased by $113.98 \mathrm{~kg} / \mathrm{ha}$, which is $56.95 \%$ higher than in the control version. Additional application of leaf feeding by Plantafol contributed to an increase in seed yield by $82.59 \mathrm{~kg} / \mathrm{ha}$ compared to control. The optimal combination of mineral fertilizers with organic fertilizers Bioproferm increased the yield of tomato seeds to $132.09 \mathrm{~kg} / \mathrm{ha}$. The hike for a variant without fertilization is $62.86 \%$. An integrated combination of organic fertilizers and foliar nutrition helps to obtain maximum seed yield regardless of variety, seeding scheme and year of research. On average, over three years, the yield on a complex fertilizer variant was $148.86 \mathrm{~kg} / \mathrm{ha}$. The increase relatively the control variant is $67.04 \%$. By the research was set straight strong functional correlation between yield fruits and seeds, the correlation coefficient was $r=0.95$ (Figure).

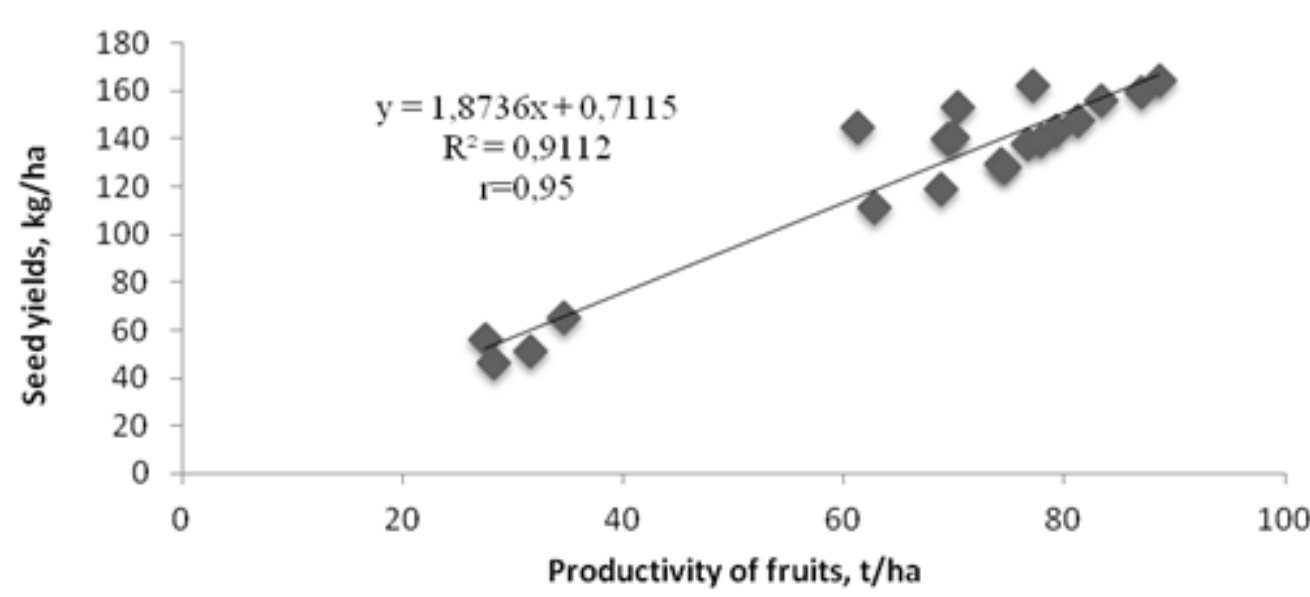

Fig. 1. The correlation between yield fruit and seed yield (average for 2016-2018 years)

An important factor in increasing the yield and improving the quality of agricultural products is highyielding varieties and high-grade seeds. Many years of experience show the importance of using high quality seeds for sustainable crop yields. The quality of the seeds is a complex integral indicator, which is determined by the sowing and varietal properties. In conditions of market relations from them, to a large extent, the overall efficiency of seed production depends [14]. The main characteristics of the sowing properties of the seeds are the weight of 1000 seeds, energy of germination, laboratory and field germination [15]. Weight 1000 seeds obtained on research areas in 2016 were in the range from 2.98 to $3.39 \mathrm{~g}$, in $20173.07-3.49 \mathrm{~g}$, in $20182.85-3.35 \mathrm{~g}$, on average for two years of research 2.91-3.39 g. Weight 1000 seeds Jubilee variety was $0.02 \mathrm{~g}$ higher than the Legin variety $(3.16 \mathrm{~g})$. For a wide-ranging scheme of $150 \mathrm{sm}$, the surcharge was $0.1 \mathrm{~g}(3.1 \%)$. In general, the use of fertilizers contributed to an increase in weight of 1000 seed $0.06-0.11 \mathrm{~g}$ compared to control.

Seeds with high energy of germination provide friendly stairs, which are less depressed with weeds and more resistant to adverse conditions, plants are better developed and ripen evenly. The germination energy for the Legin variety in 2016 was in the range of $83-85 \%$, in $2017-82-87 \%$, in $2018-83-87 \%$. The energy of germination of tomato seeds of the Jubilee variety in 2016 amounted to $81-87 \%$, in 2017 $82-87 \%$, in $2018-84-90 \%$. On average, over three years of research, the energy of germination of the Legin is on $2.0 \%$ less, thanof the Jubilee ( $\mathrm{LSD}_{05} 0.7$ ). According to the wide-range scheme, an increase in germination energy was observed at $1 \%$ compared to $100+50 \mathrm{sm}$. In the control variant without fertilization, the seed germination energy was $84 \%$. The application of fertilizer has a positive effect on the energy of seed germination, an increase of $1-3 \%$.

Our studies have shown that the laboratory germination has had some variability in the experimental variants, and ranged from 95 to $100 \%$. On average, three years of research on the experiment found that the laboratory germination of the Legin and Jubilee varieties was $97 \%$ at the same level. Schemes of sowing not owned a significant effect on seed germination.

An analysis of the economic efficiency of tomato seed production showed that the highest level of profitability of $154 \%$ provided the Legin variety at the application of mineral fertilizers with foliar 
application of Plantafol under the scheme of sowing $150 \mathrm{sm}$, that is by $82 \%$ more than on the control variant. For the Jubilee variety, the best option was complex fertilizer under the scheme sowing $150 \mathrm{sm}$, the profitability rate was $148 \%$, which is $77 \%$ more than on the control.

\section{Conclusions}

The fertilization of tomato seed plants has a significant impact on seed productivity. Less influence on the yield of seeds had varietal characteristics and seeding scheme. The highest seed yield of $159.91 \mathrm{~kg} / \mathrm{ha}$ was formed by plants of Legin variety for the sowing scheme of $100+50 \mathrm{sm}$ and a complex organic-mineral fertilizer system. The quality of seeds from technology elements of growing doesn't significantly change. With the use of advanced optimal scheme of sowing and fertilization the highest level of profitability of $154,0 \%$ was provided by the industrial-type variety Legin.

\section{References}

1. Heuvelink, E. (Ed.) (2005). Tomatoes. Wallingford: CABI Publishing.

2. Erba, D., Casiraghi, M., Ribas-Agustí, A., Cáceres, R., Marfà, O., \& Castellari, M. (2013). Nutritional value of tomatoes (Solanum lycopersicum L.) grown in greenhouse by different agronomic techniques. Journal of Food Composition and Analysis, 31, 2, 245-251. doi: 10.1016/j.jfca.2013.05.014.

3. Kravchenko, V., \& Prylipka, O. (2007). Pomidor. Selektsiia, nasinnytstvo, tekhnolohii [Tomatoes. Selection, seed production, technology]. Kyiv: Agrarian science. [In Ukrainian]

4. Demir, I., Ashirov, A., \& Mavi, K. (2008). Effect of Seed Production Environment and Time of Harvest on Tomato (Lycopersicon esculentum Mill.) Seedling Growth. Research Journal of Seed Science, 1, 1, 1-10. doi: 10.3923/rjss.2008.1.10.

5. Kravchenko, V., \& Huliak, N. (2014). Pidvyshchennia efektyvnosti selektsii i nasinnytstva ovochevykh roslyn [Efficiency improvement of breeding and vegetable-seed farming]. Ovochivnytstvo $i$ bashtannytstvo: mizhvid. temat. nauk. zb. [Vegetables and melons: an interagency thematic scientific collection] (Vol. 60, pp. 15-19). Kharkiv. [In Ukrainian]

6. Korniienko, S., Rud, V., \& Kiiakh, O. (2012). The conceptual bases of developing of vegetable growing and sup-port of food safety]. Ovochivnytstvo $i$ bashtannytstvo: mizhvid. temat. nauk. zb. [Vegetables and melons: an interagency thematic scientific collection] (Vol. 58, pp. 7-17). Kharkiv. [In Ukrainian]

7. Kosenko, N. P. (2009). Urozhainist ta yakist nasinnia tomata zalezhno vid skhemy posivu i hustoty vyroshchuvannia za kraplynnoho zroshennia v umovakh Pivdennoho Stepu Ukrainy [Yield and quality of tomato seeds depending on the sowing scheme and the density of growing for dropping irrigation in the conditions of the southern Steppe of Ukraine]. Zroshuvane zemlerobstvo: zb. nauk. prats [Irrigated agriculture: a collection of scientific works]. (Vop. 52, pp. 210-217). Kherson: Timex. [In Ukrainian]

8. Balcha, K., Belew, D., \& Nego, J. (2015). Evaluation of Tomato (Lycopersicon esculentum Mill.) Varieties for Seed Yield and Yield Components under Jimma Condition, South Western Ethiopia. Journal of Agronomy. Asian Network for Scientific Information, 14, 4, 292-297. doi: 10.3923/ja.2015.292.297.

9. Chakradhar Patra, Laxmi Priya Sahoo, Supriya Das \& Anuj Kumar Rai (2017). Effect of BioFertilizers and Micronutrientson Seed Yield and Quality in Tomato (Lycopersicon esculentum Mill.). International Journal of Science, Environment and Technology, 6, 2, 1526-1534.

10. Nighat, M., Faheema, M., Rehana, J., Khan, S. H, Ashutosh, K, Bhat, R. A., \& Tariq, A. B. (2018). Physiological Responses and Cost Benefit Analysis of Tomato (Solanum Lycopersicon L.) Seed Crop in Relation to Foliar Application of B and Zn under Temperate Open Field Conditions. Agricultural Research \& Technology: Open Access Journal, 14, 2, 1-4. doi: 10.19080/ARTOAJ.2018.14.555913.

11. Honcharenko, V. lu., \& Korniienko, S. I. (Eds.) (2014). Udobrennia ovochevykh i bashtannykh kultur [Fertilization of vegetable and melon cultures]. Monograph. Vinnytsia: Nilan-LTD. [In Ukrainian]

12. Bondarenko, G. L., \& Jakovenko, K. I. (2001). Metodyka doslidnoi spravy v ovochivnytstvi $i$ bashtannytstvi [Methodology of anexperience business in vegetable growing and water-melon]. Kharkiv: Osnova. [In Ukrainian]

13. Vozhegova, R. A. (Ed.) (2014). Metodyka polovykh i laboratornykh doslidzhen na zroshuvanykh zemliakh [Methodology of the field and laboratory researches is on irrigable earth]. Herson: Grin D. S. [In Ukrainian]

14. Malko, A. M. (2009). Kachestvo semyan, sortosmena i sortoobnovlenie vazhneyshikh selskokhozyaystvennykh rasteniy: sostoyanie i tendentsii razvitiya [Seed quality, variety replacement and variety renewal of most important agricultural plants, state-of-the-art and of development]. Nasinnytstvo: teoriia $i$ praktyka prohnozuvannia produktyvnosti sortiv i hibrydiv za yakistiu nasinnia ta sadyvnoho materialu: nauk. pratsi Pivdennoho filialu NUBiP Krymskyi ahrotekhnolohichnyi universytet [Seed production: the theory and practice of forecasting the productivity of varieties and hybrids on the quality of seeds and seedlings]. (Vol. 127, pp. 248-250). Simferopol. [In Russian]

15. Horova, T. K., Havryliuk, M. M., \& Khodieieva, L. P. (Horova, T. K. (Ed.)) (2003). Nasinnytstvo i nasinnieznavstvo ovochevykh i bashtannykh kultur [Seed Production and Seed Farming of Vegetable and Melon Cultures]. Kyiv: Agrarian science. [In Ukrainian] 